\title{
Morphological variation in Lissanthe strigosa (Epacridaceae) in New South Wales
}

\author{
J.M. Powell and B.M. Wiecek
}

\begin{abstract}
J.M. Powell and B.M. Wiecek (National Herbarium of New South Wales, Royal Botanic Gardens, Sydney NSW Australia 2000) 1994. Morphological variation in Lissanthe strigosa (Epacridaceae) in New South Wales. Telopea 5(4): 735-741. The morphological variation of populations of Lissanthe strigosa in New South Wales was investigated. Two taxa can be recognized. One, with short fine leaves, equates with $L$. strigosa $(\mathrm{Sm}$.) R. Br.; it is found on clayey soils in the Central Coast and in the southernmost parts of the North Coast botanical subdivisions. The other, with longer, wider leaves, equates with L. subulata R. Br.; it is found in rocky, skeletal and well-drained soils and is widespread in coastal, tableland and western slopes subdivisions. However, as the taxa have most attributes showing overlapping ranges we consider they should be recognized as subspecies rather than species and the combination L. strigosa (Sm.) R. Br. subsp. subulata ( $R$. $\mathrm{Br}$.) J. Powell is made. A survey of specimens from other states indicates that $L$. strigosa subsp. subulata only occurs. Lectotypes are chosen for the names Styphelia strigosa Sm. and Lissanthe subulata R. Br.
\end{abstract}

\section{Introduction}

Lissanthe strigosa $(\mathrm{Sm}$.$) R. Br. as generally accepted in New South Wales (Beadle,$ Evans \& Carolin 1982, Beadle 1980, Burbidge \& Gray 1976) is a widely distributed species occurring in most botanical subdivisions from the coast through the tablelands to the western slopes and just into the western plains. It is found also in Queensland, Victoria, Tasmania and South Australia. While preparing a treatment of the genus for the Flora of New South Wales a taxon with short, fine-leaves was recognized from the Central Coast and the southernmost parts of the North Coast botanical subdivisions, distinct from a widespread longer, coarser-leaved taxon. Although some apparently intermediate specimens were present, the morphological variation did not appear to be continuous and it was considered worthwhile to investigate the variation further.

\section{Taxonomic history}

Robert Brown established the endemic Australian genus Lissanthe (Brown 1810) with six species placed in three sections. Only his first section is discussed here. It consists of $L$. sapida, $L$. strigosa and $L$. subulata, and is the only section that has remained in the genus, the other sections having been transferred to Leucopogon and Brachyloma (Bentham 1869, Mueller 1882, 1889, Willis 1956).

Bentham (1869) accepted L. sapida R. Br. but merged Lissanthe subulata R. Br. with $L$. strigosa stating 'In Brown's herbarium, small-leaved specimens from Port Jackson and from Tasmania represent $L$. strigosa and his $L$. subulata from Grose river has much larger leaves, but in a large number of specimens from various localities the two can no longer be separated even as marked varieties.'

The attributes cited by Brown (1810) as distinguishing the two taxa were the inflorescence structure and number of flowers (racemose, 4-5-flowered in L. subulata, where- 
as subspicate and few-flowered in $L$. strigosa), the presence or absence of hairs on the branches (glabrous in L. subulata, pubescent in L. strigosa) and the depth of grooves in the endocarp of the drupe (10-striate in L. subulata, scarcely grooved in $L$. strigosa). Both species were stated to have linear-subulate leaves, with those of $L$. subulata being $12 \mathrm{~mm}$ long.

While the characters used by Brown assist in delimiting the taxa they are not as definitive as leaf density, leaf width and leaf-tip length. The present study indicates two taxa can be recognized in New South Wales on the basis of both qualitative and quantitative morphological attributes. The ranges of most of these attributes overlap to some extent, however, and there are no obvious differences in flowering times. When the taxa are sympatric differences in habitat preference are found. It is considered that the two taxa should be recognized as subspecies of $L$. strigosa.

\section{Methods}

Specimens of Lissanthe strigosa s. lat. were sampled from the Central Coast and from the rest of the distributional range of the species in New South Wales. The following attributes were investigated: branchlet hairiness, leaf length, leaf width, leaf-tip length, structure of leaf in transverse section (number of vascular bundles, vein ridges and furrows), number of flowers per inflorescence, pedicel length, sepal length, corollatube length, corolla-tube width, corolla-lobe length, fleshiness of drupe, depth of grooving in endocarp (as shown in transverse section).

Leaves and inflorescences were selected carefully from comparable branchlet positions and observed and measured using a binocular dissecting microscope. Transverse sections were made of leaves rehydrated in heated $70 \%$ ethanol and fruits were treated with $10 \%$ nitric acid to remove the fleshy mesocarp. Mature fleshy fruits drop readily from the plant; they are rarely seen in the field and almost never present on herbarium specimens. Therefore immature fruits at apparently comparable stages of development were selected for observation of fruit endocarp structure. Data for flowering and fruiting times, habitat, habit and flower and fruit colour were recorded from specimen labels and populations within the Sydney region were studied in the field.

The morphological data were tabulated and the most discriminating attributes selected for phenetic analyses using the PATN programmes (Belbin 1989a, 1989b): leaf length, leaf width, leaf-tip length, sepal length, number of leaves per cm (leaf density; see Figure 1).

A preliminary sorting into fine- and coarse-leaved groups indicated that the majority of the specimens were coarse-leaved. Two subsets of the latter were chosen for comparison with the fine-leaved specimens (numbering 19) in the phenetic analyses. The first subset comprised 18 Central Coast specimens while the second subset, of 12 specimens, included representatives from each of the other botanical subdivisions.

Study of the type specimens of $L$. strigosa and $L$. subulata indicated the fine-leaved specimens equated with $L$. strigosa while the coarse-leaved specimens matched L. subulata. For convenience these names were applied to the different groups of specimens.

A hierarchical classification was produced using the Gower metric association measure together with Flexible UPGMA or Group Average Fusion. The association measure chosen is range-standardised and therefore the most appropriate for continuous biological data. A dendrogram summarizing the results of the group fusion was produced (using DEND) and the groups defined from the dendrogram (using GDEF). 
Table 1. Comparison of qualitative and quantitative attributes in Lissanthe strigosa s. lat.

\begin{tabular}{|c|c|c|c|}
\hline Attribute & $\begin{array}{l}\text { L. strigosa } \\
\text { CC/NC group }\end{array}$ & $\begin{array}{l}\text { L. subulata s. str. } \\
\text { CC group }\end{array}$ & $\begin{array}{l}\text { L. subulata } \\
\text { NSW other areas group }\end{array}$ \\
\hline Lamina length $(\mathbf{m m})$ & $3.4-5.8$ & $6.1-11.2$ & $7.2-16.5$ \\
\hline Lamina width (mm) & $0.5-0.8$ & $0.7-1.2$ & $0.8-2.2$ \\
\hline Leaf-tip length (mm) & $0.4-0.7$ & $0.7-1.5$ & $0.6-1.9$ \\
\hline $\begin{array}{l}\text { No. vascular bundles } \\
\text { per leaf }\end{array}$ & 3 & 3,5 or 7 & 5 or 7 \\
\hline Branchlet hairiness & $\begin{array}{l}\text { hispidulous, } \\
\text { rarely scabrous }\end{array}$ & $\begin{array}{l}\text { scabrous to } \\
\text { hispidulous, rarely } \\
\text { pubescent }\end{array}$ & $\begin{array}{l}\text { scabrous to } \\
\text { hispidulous }\end{array}$ \\
\hline No. leaves/ cm & $11-21$ (mean 17.5) & $4-15($ mean 8$)$ & 4-9 (mean 6) \\
\hline Pedicel length (mm) & $0.7-1.2$ & $0.6-1.6$ & $0.7-1.4$ \\
\hline No. flowers/ inflorescence & $3-11($ mean 6$)$ & $3-8($ mean 5.6$)$ & 4-10(mean 6.4) \\
\hline Sepal length (mm) & $0.8-1.1$ & $0.9-1.2$ & $1.0-1.4$ \\
\hline Corolla-tube length $(\mathrm{mm})$ & $1.9-3.2$ & $2.5-3.7$ & $2.3-5.0$ \\
\hline Corolla-lobe length (mm) & $0.9-1.2$ & $1.0-1.4$ & $1.0-1.6$ \\
\hline Fruit endocarp structure & $\begin{array}{l}10-12 \text { unequal ribs } \\
\text { or obscurely ribbed }\end{array}$ & $10-12$ equal ribs & $10-12$ equal nibs \\
\hline
\end{tabular}
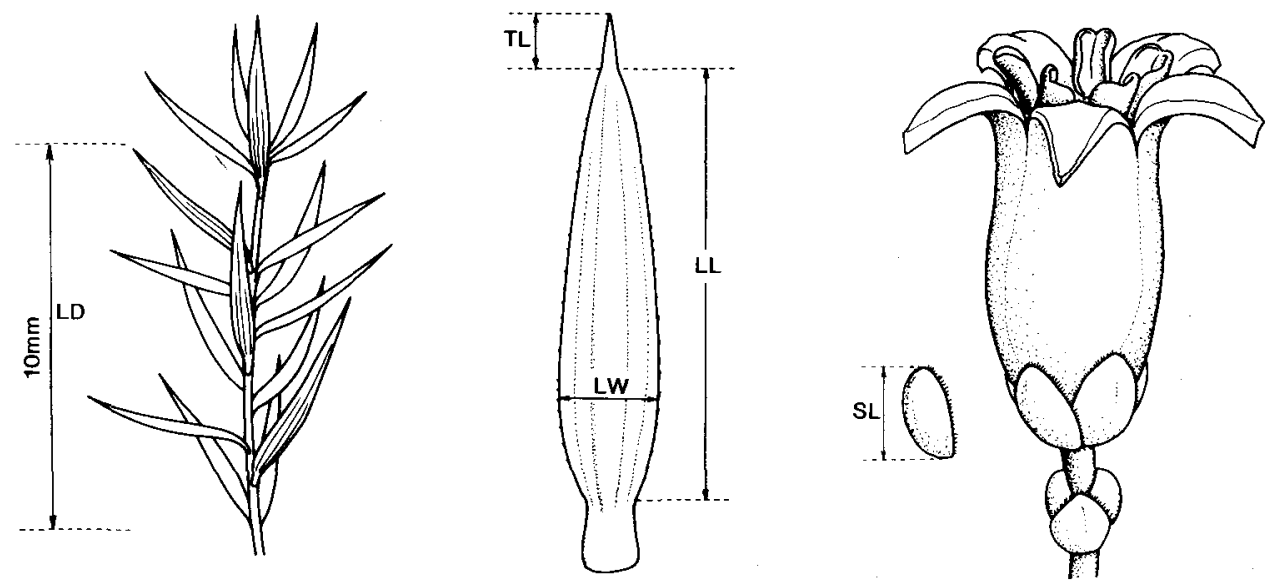

Figure 1. Attributes of Lissanthe strigosa s. lat. studied and measured: LL: leaf-blade length; LW: leaf-blade width; TL: leaf-tip length; SL: sepal length; LD: leaf density (number of leaves $/ \mathrm{cm}$ on branchlet). 
The attributes most responsible for forming the groups were determined using the GSTA programme. Ordination of the data used SSH multidimensional scaling on the Gower metric association matrix and was displayed as a scatter diagram (using SCAT). How well each attribute related to the ordination was determined by deriving principal correlation axes using the PCC programme.

A survey of specimens of $L$. strigosa s. lat. from other parts of its distributional range (Queensland, Victoria, Tasmania, South Australia) was undertaken after these analyses were completed to determined the distributional range of the fine-leaved and coarse-leaved taxa.

\section{Results}

In Table 1 the ranges of attributes studied for the various groups of specimens are given. In L. strigosa s. str. specimens the leaves are often twice as densely crowded on the branchlets, are always shorter, usually also narrower, and the leaf tips are shorter than in $L$. subulata specimens. Also, the L. strigosa s. str. specimens are consistently 3veined while the $L$. subulata specimens are usually 5-7-veined. The flowers of the $L$. strigosa s. str. group tend to be smaller than those of the L. subulata groups but the ranges of measurements for sepal length, corolla-tube length and width and corollalobe length overlap to a considerable extent. In number of flowers per inflorescence and in branchlet hairiness similar ranges were recorded.

The PATN analyses of the two Central Coast specimen groups (19 L. strigosa s. str., 18 L. subulata) and of the three groups together (the other subset of $12 \mathrm{~L}$. subulata specimens being from other botanical regions) resulted in similar classifications and ordinations. The classification formed two major groups which clearly separated the $L$. strigosa s. str. group from both L. subulata specimen groups, and the group 'statistics' indicated that the attributes of greatest importance in distinguishing the groups were leaf length and leaf density, and that leaf width and leaf-tip length were also useful. Within the L. subulata groups the Central Coast and Central Tablelands specimens were segregated to some extent from the other tablelands, western slopes and plains specimens. The ordination (Figure 2) illustrates the distinctiveness of the groups and the vectors responsible for their separation.

\section{Flowering and fruiting times}

The L. strigosa s. str. group flowers between July and September and fruit is recorded from July to November. The Central Coast $L$. subulata group flowers mainly between June and September, rarely in February, and fruit is recorded July to November, rarely also February. From other botanical subdivisions flowering in the $L$. subulata group has been recorded from May to January (mainly August-October) with fruit recorded from June to February.

\section{Habitat preferences}

Field study of the Sydney populations showed that the L. strigosa s. str. group occupied fine light yellow-grey or orange-brown clayey soils that are probably subjected to periodic inundation and are poorly drained. The $L$. subulata group was collected from rocky ridge and slope areas with skeletal and well-drained soils. In a transect along Cliftonville Road from near Maroota to the Hawkesbury River the two taxa 
were found growing near each other. The fine clay soils on the ridgetop were occupied by the L. strigosa s. str. plants, the rocky roadside slopes by the L. subulata plants.

Herbarium label information indicated only that the Central and North Coast L. strigosa s. str. plants had been collected from dry sclerophyll open forest or woodland on sandy loams or gravelly soils on shales or on sandstone adjacent to shale. The L. subulata plants from Central Coast areas had been collected from similar vegetation. types and from shrublands on sandstone. The L. subulata plants from other areas occupied rocky ridges and stoney slopes growing in loamy and clayey soils over sedimentary and igneous bedrock.

\section{Specimens from other States}

A survey of 40 specimens from Queensland, Victoria, Tasmania and South Australia showed a considerable range of variation in leaf attributes but all equated with the L. subulata group rather than the $L$. strigosa s. str. group.
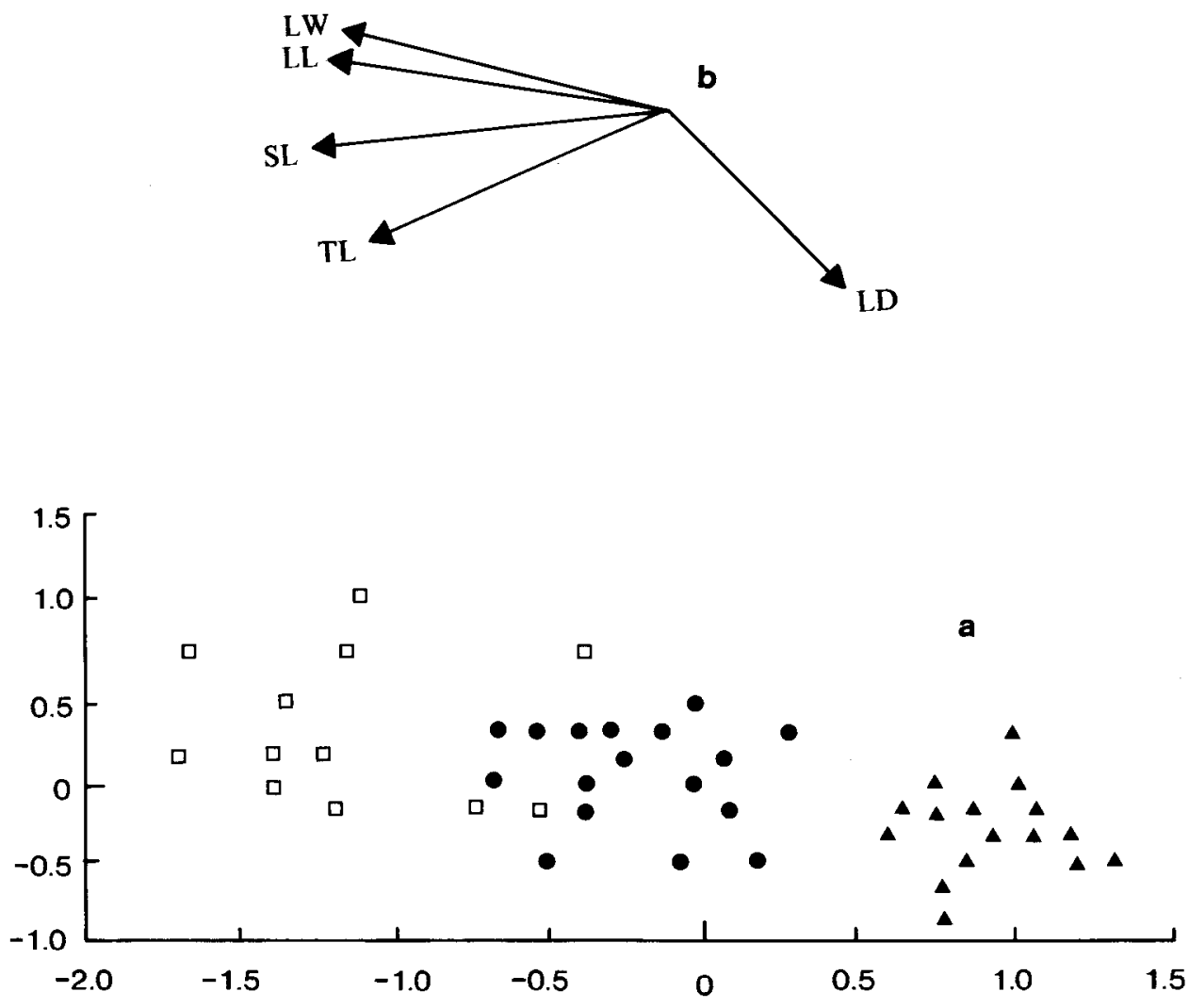

Figure 2. Morphometric analysis of Lissanthe strigosa s. lat. (a) Scatter diagram of ordination of specimens: $\Delta$, L. strigosa s. str. CC/NC specimens; $\bullet$, L. subulata CC specimens; $\square$, L. subulata specimens from other botanical subdivisions. (b) Vectors showing direction of maximum linear correlation between each of the five attributes and the ordination space. LL: leaf-blade length; LW: leaf-blade width; SL: sepal length; TL: leaf-tip length; LD: leaf density. 


\section{Taxonomic conclusions}

The data indicate that while two taxa can be recognized in New South Wales on the basis of quantitative differences in a number of attributes, the ranges of other quantitative and of qualitative attributes overlap to various extents. There are no obvious differences in flowering times but habitat differences are present where the two taxa are sympatric. It is concluded that the two taxa should be recognized as distinct subspecies of $L$. strigosa. The formal nomenclature changes are made below.

\section{L. strigosa (Smith) R. Br.}

(Brown 1810: 540)

\section{BASIONYM: Styphelia strigosa Sm.}

\section{(Smith 1793:48)}

Lectotype (here designated): New South Wales, White, 1793 [J.E. Smith Herb. No. 297.16] (LINN); far left specimen.

Erect shrub, 30-100 cm high, lignotuberous; branchlets hispidulous. Leaves erect to spreading, linear to narrow-ovate, $3.4-16.5 \mathrm{~mm}$ long, $0.5-2.2 \mathrm{~mm}$ wide, acute to subulate, with aristate tip; base cuneate; petiole $0.6-1.3 \mathrm{~mm}$ long; lamina discolorous, upper surface flat or convex, lower surface strongly and deeply 1-5-ribbed; margin usually entire. Flowers erect or spreading, 2-11 together, in inflorescences up to $9 \mathrm{~mm}$ long; peduncles pubescent; pedicels $0.6-1.6 \mathrm{~mm}$ long, pubescent. Bracts $0.5-1.0 \mathrm{~mm}$ long, obtuse; bracteoles $0.8-1.3 \mathrm{~mm}$ long, obtuse. Sepals pinkish, ovate to suborbicular, 0.8-1.4 mm long, obtuse, with margins ciliolate to ciliate. Corolla-tube urceolate, white, 1.9-5.0 mm long, glabrous externally, with scattered hairs internally over the upper half; lobes erect to spreading, 0.9-1.6 mm long, glabrous or papillose. Anthers 0.6-1.1 mm long. Ovary spherical or ellipsoid, densely puberulent, 5-7-locular; style filiform, often sulcate or several-ribbed with spreading hairs over the lower half or two-thirds, not exserted from the corolla-tube; nectary annular, $0.25-0.5 \mathrm{~mm}$ high. Fruit greatly exceeding the sepals, depressed-globose, $2.5-3.5 \mathrm{~mm}$ high, $3.2-4.0 \mathrm{~mm}$ wide, flattopped, ribbed, echinulate to puberulent.

\section{Key to subspecies}

Leaves dense on branchlets $(11-21 / \mathrm{mm}$, mean $17.5 / \mathrm{mm}$ ), linear-subulate, $3.4-5.8 \mathrm{~mm}$ long, $0.5-0.8 \mathrm{~mm}$ wide, with tip $0.4-0.7 \mathrm{~mm}$ long, usually with a single thick midrib grooved on each side abaxially; flowers with sepals $0.8-1.1 \mathrm{~mm}$ long, corolla-tube 1.9-3.2 mm long, lobes 0.9-1.2 $\mathrm{mm}$ long subsp. strigosa

Leaves less dense on branchlets $(4-15 / \mathrm{mm}$, mean $8 / \mathrm{mm})$, narrow-ovate to subulate, 6.1-16.5 mm long, 0.7-2.2 $\mathrm{mm}$ wide, with tip $0.6-1.9 \mathrm{~mm}$ long, veins strongly 3-5ribbed and grooved abaxially; flowers with sepals $0.9-1.4 \mathrm{~mm}$ long, corolla-tube 2.3$5.0 \mathrm{~mm}$ long, lobes $1.0-1.6 \mathrm{~mm}$ long subsp. subulata

\section{L. strigosa (Smith) R. Br. subsp. strigosa}

TYPE: As above.

Selected specimens studied: New South Wales: North Coast: Maitland, Burgess 77, 23 Aug 1961 (NSW); Myall Range, West Wallsend, Earp, 2 Aug 1953 (NSW 239136). Central Coast: St Marys, Blakely, Jul 1920 (NSW 239129); Spence Rd, Castlereagh State Forest, James 293, 12 Jul 1983 (NSW); Richmond Rd, Powell 4823, 28 Jul 1992 (NSW); Perth St, Vineyard, Powell 4832, 5 Aug 1992 (NSW); McPherson Rd, Agnes Banks, Powell 4844, 5 Aug 1992 (NSW); Cliftonville Rd, Powell 4849, 4852, 7 Aug 1992 (NSW). 
L. strigosa (Sm.) R. Br. subsp. subulata (R.Br.) J. M. Powell comb. et stat. nov.

BAsIONYM: Lissanthe subulata R. Br. Prod.: 540 (1810).

TYPe CitATION: '(J.) v.v.'

LECTOTYPE (here designated): New South Wales: In the mountains near the Grose, $R$. Brown, 1803 [Bennett no. 2420] (BM).

Selected SPecimens Studied: New South Wales: Central Coast: Springwood, Hamilton, Sep 1914 (NSW 239289); Hill Top, Maiden \& Betche, Sep 1899 (NSW 239023); $1.5 \mathrm{~km}$ E in Parr State Recreation Area on Wheelbarrow Ridge Rd, Powell 4825, 28 Jul 1992 (NSW); $7.8 \mathrm{~km}$ W on Cattai Ridge Rd from junction with Old Northern Rd, Powell 4828, 5 Aug 1992 (NSW); Cliftonville Rd, Powvell 4850, 4855, 7 Aug 1992 (NSW). Northern Tablelands: Allyn River, Boorman, Aug 1906 (NSW 35661); Moona Plains, Walcha, Crawford, Dec 1904 (NSW 239141). Central Tablelands: Glenowlan Mt, 7 miles [11 km] NE of Capertee, Constable 5023, 23 Sep 1964 (NSW); Lawson, Sulman, 4 Aug 1914 (NSW 239279). Southern Tablelands: c. 4 km S along Nungatta Rd from its intersection with Imlay Rd, Albrecht 926, 23 Sep 1984 (NSW); $10 \mathrm{~km}$ SE of Goulburn, Slater, 3 Oct 1987 (NSW 239412). Northwestern Slopes: Warrumbungles Ranges, Forsyth, Oct 1901 (NSW 239552); Barraba, Rupp 18, Oct 1912 (NSW). Central Western Slopes: 15 miles [24 km] SW of Grenfell, Weddin State Forest, Curtin, 18 Sep 1953 (NSW 239437); Barryrenie, $20 \mathrm{~km}$ NW of Cowra, McBarron 20762, 22 Sep 1973 (NSW). Northwestern Plains: Lightning Ridge, Althofer 67, 1 Sep 1977 (NSW); SE of Pilliga, Swain 7, Aug 1913 (NSW). Queensland: Falls Creek, 4 km NW of W Haldon, Forster 4749, 2 Oct 1988 (BRI, NSW); State Forest 595 Talgai, near Mt Gammie North, Forster 11712, 27 Sep 1992 (BRI, MEL, NSW). Victoria: On the E side of the Snowy river in the vicinity of McKillops Bridge, Albrecht 2033, 2 Oct 1985 (MEL, NSW); $4 \mathrm{~km}$ N of Zumsteins, $1750 \mathrm{~m}$ SE of the Scout Camp, Grampians, Parfett 150, 17 Sep 1988 (MEL, NSW). Tasmania: Moulting Lagoon, 6 miles [10 km] NW of Coles Bay, Hemsley 6286, 14 Oct 1967 (NSW); Hobart Waterworks, Rodway 5700, Nov 1898 (NSW). South Australia: Creek crossing on Amen Corner to Kohinoor Mine road, c. $0.75 \mathrm{~km}$ SE of Amen Corner, Kangaroo Is., Jackson 4524, 26 Aug 1982 (AD, NSW); Eyre peninsula, Marble Range, E. Face, W of Marble Range station, Symon 11623, 29 Sep 1979 (ADW, NSW).

\section{Acknowledgements}

We should like to thank Barry Conn for commenting on a draft and David Mackay for drawing the Figures.

\section{References}

Beadle, N.C.W. (1980) Students Flora of North Eastern New South Wales Part 4. (University of New England: Armidale).

Beadle, N.C.W., Evans, O.D. \& Carolin, R.C. (1982) Flora of the Sydney Region Edn. 3. (A.H. \& A.W. Reed: Sydney).

Belbin, L. (1989a) Technical reference PATN pattern analysis package (CSIRO: Canberra).

Belbin, L. (1989b) Users guide PATN pattern analysis package (CSIRO: Canberra).

Bentham, G. (1869) Flora Australiensis, vol. 4. (Reeve \& Co.: London).

Brown, R. (1810) Prodromus Florae Novae Hollandiae et Insulae Van Diemen (London).

Burbidge, N.T. \& Gray, M. (1976) Flora of the Australian Capital Territory (Australian National University Press: Canberra).

Mueller, F. von (1867) Fragmenta Phytographiae Australiae 6: 29-76. (Govt. Printer: Melbourne). Mueller, F. von (1882) Systematic Census of Australian Plants Part I-Vasculares. (McCarron Bird: Melbourne).

Mueller, F. von (1889) Second Systematic Census of Australian Plants Part-Vasculares. (McCarron Bird: Melbourne).

Willis, J.H. (1956) Two puzzling alpine heaths. Victorian Naturalist 73: 56-58. 